\title{
Periodontal disease and its complications in cats from a shelter in the Central Region of Rio Grande do Sul ${ }^{1}$
}

\author{
Roberto M. Maciel², Renata D. Mazaro², João P.F. Silva², Douglas M. Lorenzetti³, \\ Alana Herbichi ${ }^{4}$, Milena C. Paz ${ }^{4}$, Cristiane C. Danesi ${ }^{5}$ and Rafael A. Fighera ${ }^{5 *}$ (D)
}

\begin{abstract}
Maciel R.M., Mazaro R.D., Silva J.P.F., Lorenzetti D.M., Herbichi A., Paz M.C., Danesi C.C. \& Fighera R.A. 2020. Periodontal disease and its complications in cats from a shelter in the Central Region of Rio Grande do Sul. Pesquisa Veterinária Brasileira 40(9):696-706. Departamento de Patologia, Universidade Federal de Santa Maria, Av. Roraima 1000, Santa Maria, RS 97105-900, Brazil. E-mail: anemiaveterinaria@yahoo.com.br

Periodontal disease is the most common infectious disease that occurs in feline patients. Although it occurs in both sexes, different age groups, and any breeds, the prevalence and severity seem much higher in cats living in animal shelters. This paper aimed to describe the clinical, radiological, cytopathological, and virological aspects of periodontal disease and its complications in cats, based on these aspects and, consequently, on the importance it brings to cat feline medicine in shelter cats. For this, nine cats with periodontal disease from a single animal shelter were evaluated. These cats demonstrated a disease characterized by halitosis, excessive salivation, and oral discomfort. Lymphadenomegaly of the mandibular and retropharyngeal lymph nodes was observed in $44.4 \%$ of the cases. Oral lesions consisted of varying degrees of gingival hyperemia, complete loss of free gingival margins, and consequently gingival retraction, dental calculus deposition, dental mobility, complete exposure of the furcation of premolars and molars, and dental roots of canines and incisors, loss of bone radiopacity due to alveolar bone resorption and tooth loss. Complications included chronic ulcerative paradental stomatitis (22.2\%), faucitis $(22.2 \%)$, and chronic gingivostomatitis $(11.1 \%)$. None of the cats affected by periodontal disease was positive for FIV or FeLV. In $33.3 \%$ of the cases, cats were carriers of feline calicivirus, but not feline herpesvirus.
\end{abstract}

INDEX TERMS: Periodontal disease, cats, shelter, Rio Grande do Sul, Brazil, periodontitis, gingivitis, faucitis, stomatology, diseases of cats.

RESUMO.- [Doença periodontal e suas complicações em gatos de um abrigo na Região Central do Rio Grande do Sul.] Doença periodontal é a mais comum doença infecciosa que ocorre em pacientes felinos. Embora ocorra em gatos de

\footnotetext{
${ }^{1}$ Received on March 11, 2020.

Accepted for publication on March 25, 2020.

${ }^{2}$ Graduate Program in Veterinary Medicine, emphasis on Pathology and Veterinary Clinical Pathology, Patologia e Patologia Clínica Veterinária, Centro de Ciências Rurais (CCR), Universidade Federal de Santa Maria (UFSM), Avenida Roraima 1000, Camobi, Santa Maria, RS 97105-900, Brazil.

${ }^{3}$ Scholarship from PIBIC/CNPq/UFSM, Curso de Medicina Veterinária, Centro de Ciências Rurais (CCR), Universidade Federal de Santa Maria (UFSM), Avenida Roraima 1000, Camobi, Santa Maria, RS 97105-900, Brazil.

${ }^{4}$ Curso de Medicina Veterinária, Centro de Ciências Rurais (CCR), Universidade Federal de Santa Maria (UFSM), Avenida Roraima 1000, Camobi, Santa Maria, RS 97105-900, Brazil. Bolsista PROBIC/FAPERGS/UFSM.

${ }^{5}$ Departamento de Patologia, Centro de Ciências da Saúde (CCS), Universidade Federal de Santa Maria (UFSM), Av. Roraima 1000, Camobi, Santa Maria, RS 97105-900. *Corresponding author: anemiaveterinaria@yahoo.com.br
}

ambos os sexos, diferentes faixas etárias e quaisquer raças, a prevalência e a gravidade parece muito maior em gatos que vivem em abrigos para animais. Baseado nesses aspectos e, consequentemente, na importância que ela traz para a medicina felina de gatos de abrigos, o objetivo desse artigo é descrever os aspectos clínicos, radiológicos, citopatológicos e virológicos da doença periodontal e suas complicações em gatos. Para isso, nove gatos com doença periodontal oriundos de um único abrigo de animais foram avaliados. Esses gatos demonstraram uma doença caracterizada por halitose, salivação excessiva e desconforto oral. Linfadenomegalia dos linfonodos mandibulares e retrofaríngeos foi observada em $44,4 \%$ dos casos. As lesões orais consistiam de graus variados de hiperemia gengival, perda completa das margens gengivais livres e, consequentemente, retração gengival, deposição de cálculo dental, mobilidade dentária, exposição completa da furca dos pré-molares e molares e das raízes dentárias dos caninos e incisivos, perda de radiopacidade óssea devido à 
reabsorção de osso alveolar e perda dentária. Complicações incluíram estomatite paradental ulcerativa crônica $(22,2 \%)$, faucite $(22,2 \%)$ e gengivoestomatite crônica $(11,1 \%)$. Nenhum dos gatos afetados pela doença periodontal foi positivo para FIV ou FeLV. Em 33,3\% dos casos, os gatos eram portadores do calicivírus felino, mas não do herpesvírus felino.

TERMOS DE INDEXAÇÃO: Doença periodontal, gatos, Rio Grande do Sul, Brasil, periodontite, gengivite, faucite, estomatologia, doenças de gatos.

\section{INTRODUCTION}

Periodontal disease (PD) is the inflammatory condition of the oral cavity most commonly diagnosed in feline medicine (Chaudieu \& Blaizoit 1999), with a prevalence of up to $85 \%$ of adult cats older than four years of age, in a determined community (Watson 1994). PD begins with gingivitis promoted by the establishment of distinct bacterial communities (biofilm) on the dental surface and gingival cavities that progresses in the absence of adequate treatment, and inflammation of the other elements of the periodontium, that is, periodontitis (Gawor et al. 2006). In addition to soft tissue injuries, which cause oral pain and discomfort, periodontal disease compromises tooth support. It affects the periodontal ligament, cementum, and alveolar bone, into which the teeth are inserted (Whyte et al. 2014). Despite much progress in understanding periodontal disease in humans and animals in recent years, periodontal disease still has essential gaps to be clarified. Also, in the Central Region of Rio Grande do Sul (RS), periodontal disease is seen with high frequency in cats that live in animal shelters (Silva et al. 2019). A deeper understanding of the interaction between the bacteria present in the biofilm, the viruses that most commonly infect domestic cats, the inflammatory response, bone, and tissue injuries is necessary. This study aimed to evaluate the clinical, radiological, cytopathological and virological changes of cats from a shelter located in the Central Region of RS.

\section{MATERIALS AND METHODS}

The cases included in this study ( $\mathrm{n}=9$ ) occurred in mid-2018, in the municipality of Santa Maria, located in the Mesoregion of the Western Center of Rio Grande do Sul. Only cases diagnosed as periodontal disease were considered through clinicopathological criteria. The criteria used were those previously established by Ingham et al. (2002) and applied during this period from consultations to different editions of the leading textbook on veterinary dentistry (Holmstrom 2012). For comparison, three healthy cats have undergone the same assessments that will be described below.

The oral cavity's physical examination was performed according to criteria already established in the veterinary literature (Bellows 2010). It includes the extra-oral examination (skull examination), in which facial symmetry, volume of draining regional lymph nodes and presence of fistulas or any periorbital lesions that may be related to some oral condition; and the intraoral examination, in which gums are evaluated (including adherent gums, free gingival margins and gingival sulcus), cheeks, tongue, oral floor, hard and soft palates and palatoglossal and glossopharyngeal arches, as well as dental mobility, dental fractures and furcation exposure.

As for tartar (stone accumulation index), the teeth were classified into grades I to III, according to Bellows (2010). The characteristics of each degree are: I) small amount of calculus, which covers less than half of the crown; II) moderate amount of stone, which covers more than half of the crown; and III) marked amount of calculus, characterized by gingival retraction with an accumulation of calculus involving the tooth root (root calculus).

As for tooth mobility (tooth mobility index), teeth were classified into grades I to III, according to Holmstrom et al. (1992). The characteristics of each degree are: I) little mobility, so small that it cannot be measured in millimeters; II) moderate mobility, with movement of $1 \mathrm{~mm}$ in at least one direction, other than the alveolar one; and III) marked mobility, with a movement of more than $1 \mathrm{~mm}$ in all directions or at least towards the tooth socket.

Regarding furcation exposure (furcation exposure index), the teeth were classified into grades I to III, according to Holmstrom et al. (1992). The characteristics of each grade are: I) observable furcation, at the level of the gum line, without penetration of a periodontal probe; II) furcation more easily observed, with penetration of a periodontal probe, but without extending to the other side; and III) completely exposed furcation, with transfixation of the periodontal probe.

The radiographic study of teeth and the bone-alveolar structure was carried out with digital X-ray equipment (Sound-Eklin Digital X-Ray), 45kV, and 35mAs, the focal distance of the film of approximately $40 \mathrm{~cm}$. The images were captured from the left and right dorsolateral oblique projections in the mandible and left and right ventrolateral in the maxilla, according to Debowes (2008).

The cats were anesthetized with a combination of ketamine hydrochloride $(20 \mathrm{mg} / \mathrm{kg})$ and xylazine hydrochloride $(2 \mathrm{mg} / \mathrm{kg})$ to perform the intraoral physical examination and radiographic study of the teeth and bone-alveolar structure. The administration was via deep intramuscular (IM) in the pelvic limb.

For cytopathological evaluation of the oral mucosa, swabs were introduced into the oral cavity, rolled firmly over the gums, and, subsequently, the material obtained was rubbed in glass slides. These slides were dried at room temperature, fixed in $1 \%$ triarylmethane, and stained with a combination of $0.1 \%$ xanthene solutions and $0.1 \%$ thiazides, according to the principle established by Romanowsky, sequentially (panoptic staining). For cats that presented lesion in the mucosa covering the palatoglossal and palatopharyngeal arches, a region described in feline medicine as fauces, another swab was used in the same collection system (bearing), fixation, and coloring of the obtained samples.

For the cytopathological evaluation of local draining lymph nodes, a non-aspirating puncture with a fine needle (capillary puncture) was performed. The material obtained was deposited on glass slides for later spreading by another glass slide (squash). These slides were treated in the same way as previously described for the oral samples.

Cats were tested for possible infections by feline leukemia virus (FeLV), feline immunodeficiency virus (FIV), feline calicivirus (FCV), and feline herpesvirus (FHV). swabs were introduced into the oral cavity to detect herpesvirus and calicivirus and rolled firmly over the mucosa of the palatoglossal and palatopharyngeal arches. The samples obtained through these swabs were stored in transport medium and, subsequently, subjected to viral isolation in Crandell-Rees Feline Kidney (CRFK) cell culture, according to the methodology described by Henzel et al. (2012). Samples that showed a cytopathic effect on the inoculated cells were subjected to screening for herpesvirus by PCR using primers for the glycoprotein E gene (Argenta et al. 2017), and feline calicivirus by RT-PCR for the ORF2 gene (Henzel et al. 2012). 
Cats were tested for the presence of serum antibodies against FIV and FeLV antigen (p27 antigen) to detect infection by FIV and FeLV. About $5 \mathrm{ml}$ of blood was collected from the jugular vein, packed in vacutainer collection bottles containing EDTA potassium anticoagulant. The test used was the Snap FIV/FeLV Combo, according to the methodology provided by IDEXX Laboratories.

\section{RESULTS}

\section{Clinical findings}

All cats evaluated ( $n=9,100 \%)$, except for the control group $(n=3)$, demonstrated a disease characterized by halitosis, excessive salivation, and oral discomfort, demonstrated by continuous and persistent exposure of the tongue. No changes of the skull, such as facial asymmetry or the presence of fistulas and other injuries were observed. Persistent and moderate lymphadenomegaly of the mandibular and retropharyngeal lymph nodes (Fig.1) was observed in four of the nine cases

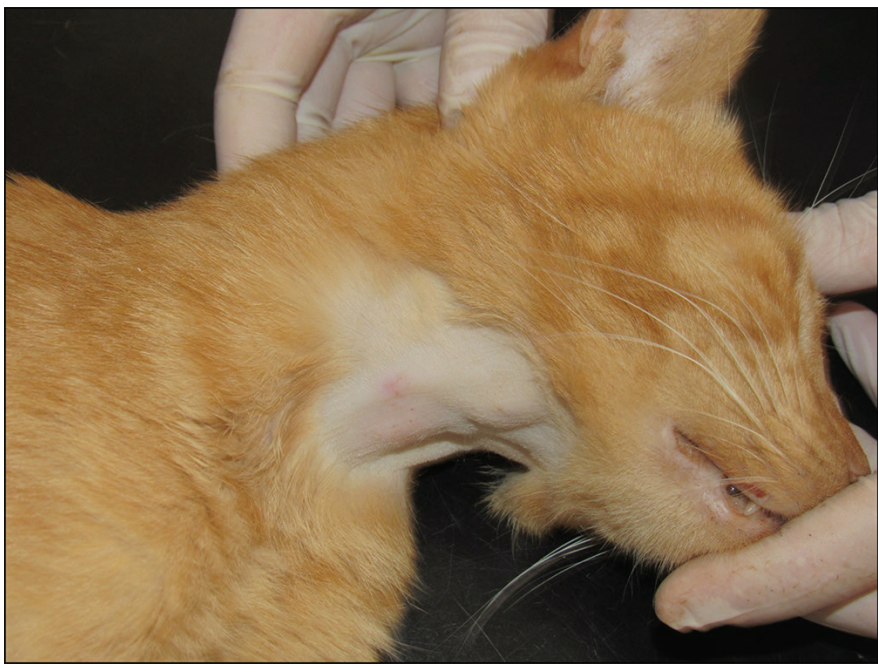

Fig.1. Right retropharyngeal lymphadenomegaly in a cat with severe periodontal disease complicated by bilateral symmetrical faucitis.

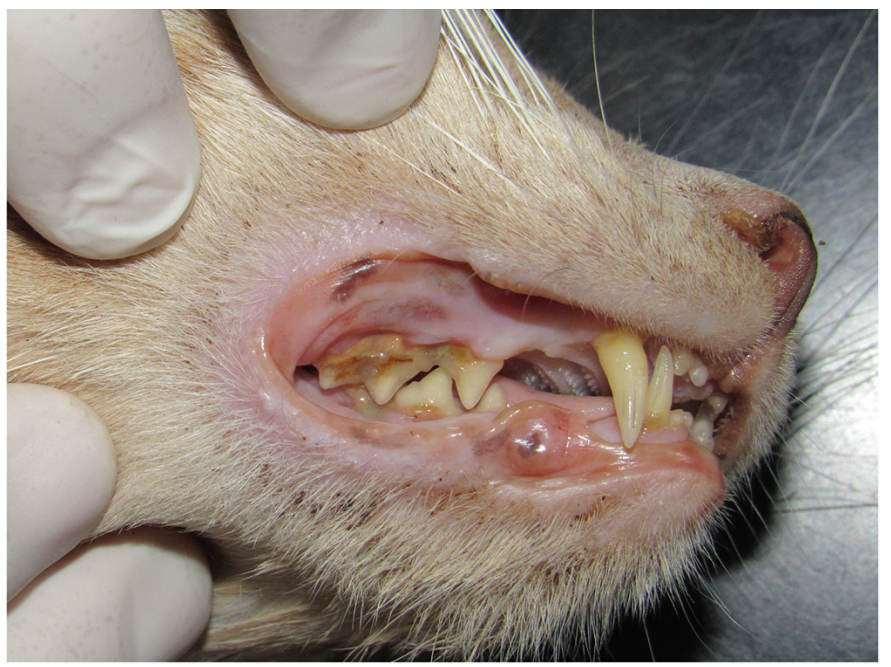

Fig.3. Moderate periodontal disease in a cat. Gingival retraction and deposition of a moderate amount of calculus cover much of the premolar quarter of the right upper arch. The ipsilateral second premolar is absent.
(44.4\%). Despite the oral disorder, all cats $(n=9,100 \%)$ had a regular nutritional status. In all patients $(n=9,100 \%)$, premolar and molar teeth were the most frequently affected, followed by canines and incisors.

Only one of the nine cats $(11.1 \%)$ had mild periodontal disease, characterized by slight redness (hyperemia) of the free gingival margin surrounding the teeth, especially the right upper premolars and the lower left canine. Additionally, a yellowish material, sometimes in the form of small mineralized concretions (dental stones), resistant to removal by salivary flow, covers a small part of the crown, mainly in areas adjacent to the neck (Fig.2). None of this patient's teeth showed mobility or furcation exposure.

In two of the nine cats (22.2\%), periodontal disease was classified as moderate. There was marked hyperemia in these patients and a slight increase in volume (edema) of the free gingival margins of all premolar, molar, and some canine teeth. Enlargement of the gingival sulcus was present in premolars

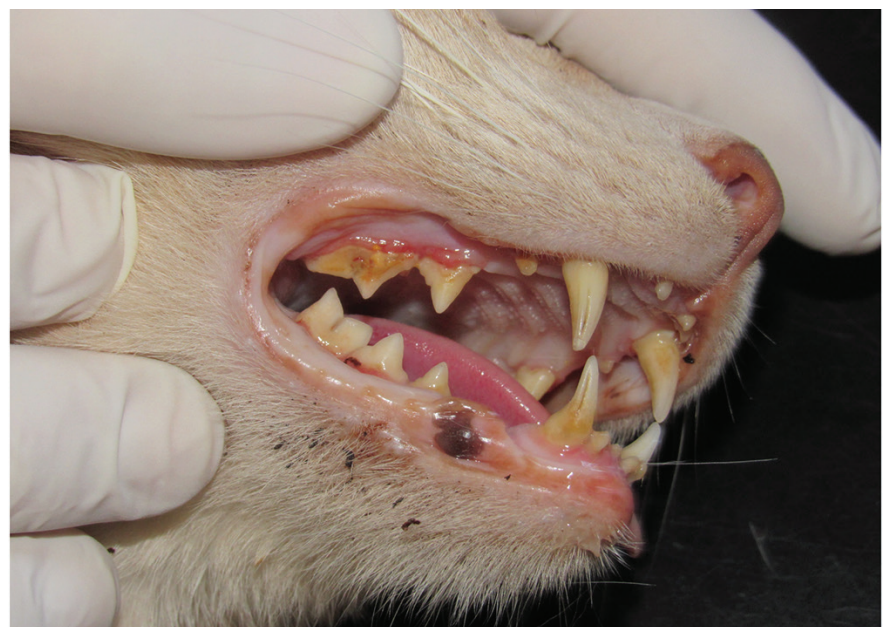

Fig.2. Mild periodontal disease in a cat. Marked gingival hyperemia and deposition of a small amount of calculus in the second, third, and fourth premolars of the right upper arch.

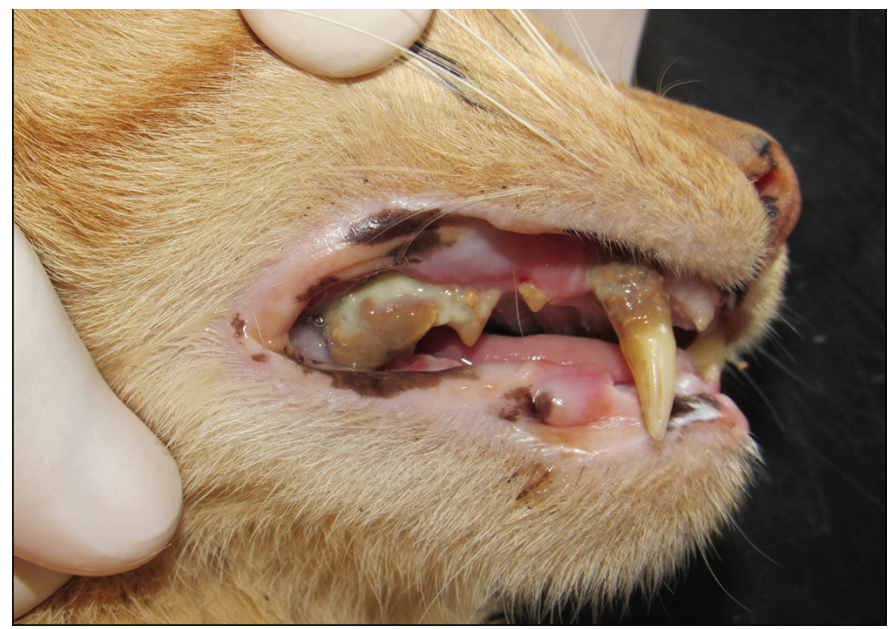

Fig.4. Marked periodontal disease in a cat. A giant stone concretion completely covers the third and fourth premolars of the right upper arch. In this case, the gingival retraction is evident even before the stone is removed. The canine tooth on the same side has the neck exposed and covered by a large amount of calculus. 
and molars. Dental calculi, particularly in premolars and molars, were present and covered all or most of the crown (Fig.3). Moderate tooth mobility, mainly bilateral or craniocaudal, was common in both premolars and molars. Gingival retraction with exposure of the dental neck and furcation of several teeth was evident.

Most cats $(6 / 9,66.7 \%)$ showed severe periodontal disease. There was a complete loss of free gingival margins in the dental arch most affected areas and marked hyperemia of the remaining adherent gingiva in these cases. Often, the adhered gingiva could only be seen after removing an immense stone (Fig.4), which, after excised, allowed the rest of the physical examination. This intense gingival retraction allowed complete exposure of the furcation of premolars and molars and the dental roots of the affected canines and incisors (Fig.5). Marked mobility, both bilateral and craniocaudal, and sometimes in the alveolar direction, was frequent. In at least

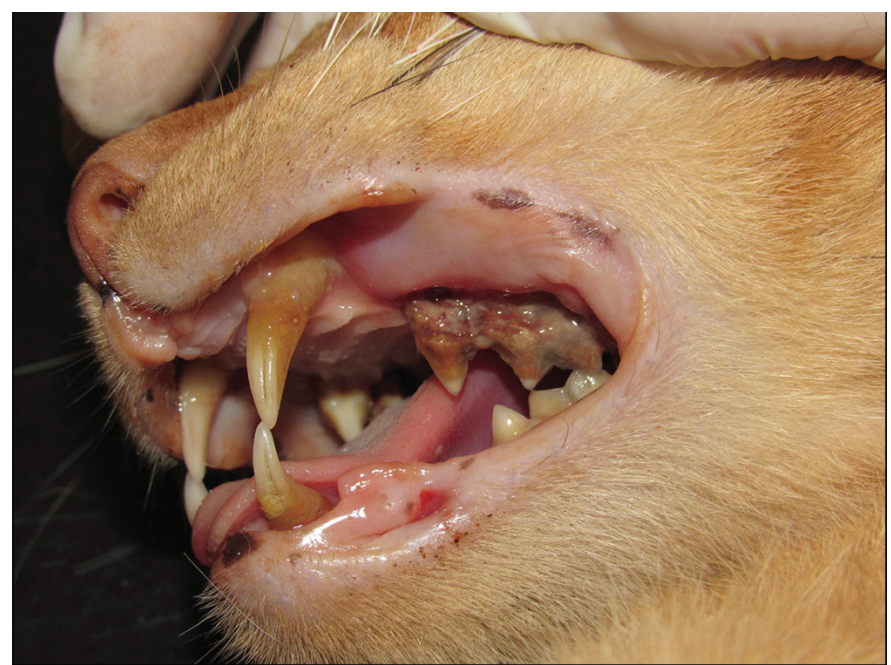

Fig.5. Marked periodontal disease in a cat. Marked gingival retraction and stone deposition in the third and fourth premolars of the left upper arch. The ipsilateral second premolar is absent. A moderate amount of calculus covers the canine tooth on the same side.

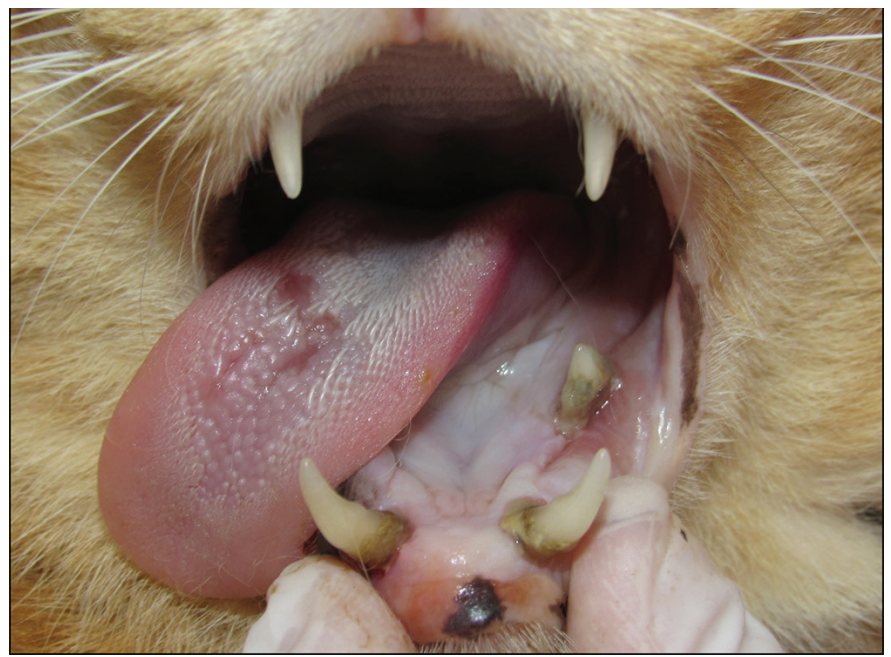

Fig.7. Marked periodontal disease in a cat. All lower incisors and lower premolars on the left side are absent. three cats (33.3\%) with severe periodontal disease, the tooth was detached during physical examination (Fig.6).

In four of the cats with periodontal disease (44.4\%), teeth were absent (Fig.7), and the tooth socket was covered with normal gingiva. In these areas, the alveolar bone thickness was noticeably thinner, increasing interdental spaces.

Other findings included cases $(2 / 9,22.2 \%)$ of stomatitis due to contact with the upper right fourth premolar tooth (P4), right unilateral faucitis $(1 / 9,11.1 \%)$ or bilaterally symmetrical $(1 / 9,11.1 \%)$ (Fig.8), and chronic gingivostomatitis (1/9, 11.1\%). Individualized results are shown in Tables 1 and 2.

\section{Radiological findings}

All cats evaluated $(n=9,100 \%)$, except for the control group $(n=3)$, demonstrated, in different areas of the dental arch, alveolar bone loss, characterized, in the mildest cases, by the loss of the horizontal bone line (Fig.9), and in the most severe cases, due to a marked decrease in the thickness of the

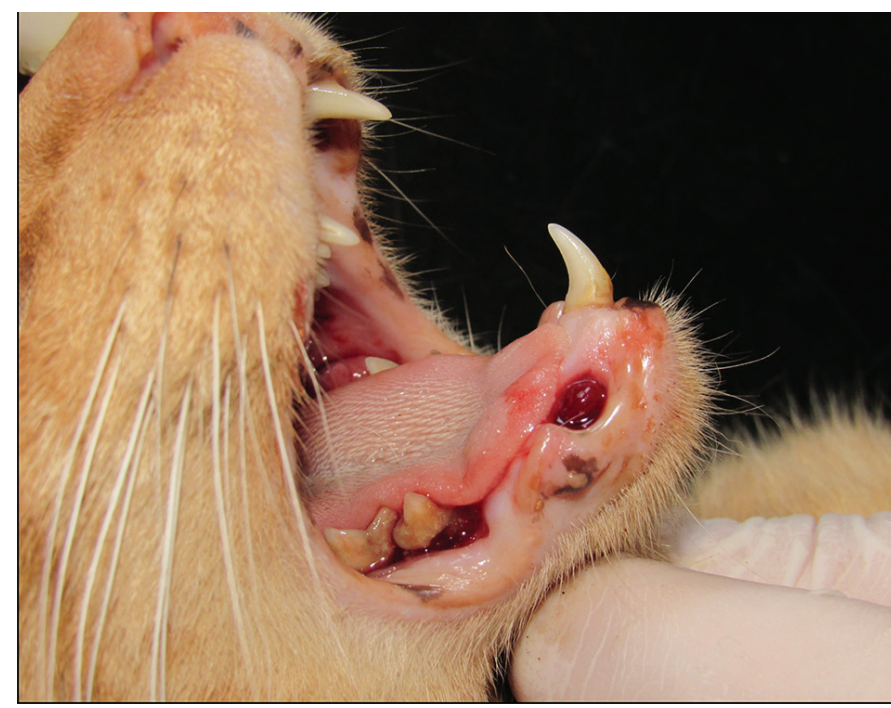

Fig.6. Marked periodontal disease in a cat. During the intraoral physical examination, the right lower canine was markedly mobile and ended up freeing itself from the tooth socket (alveolus).

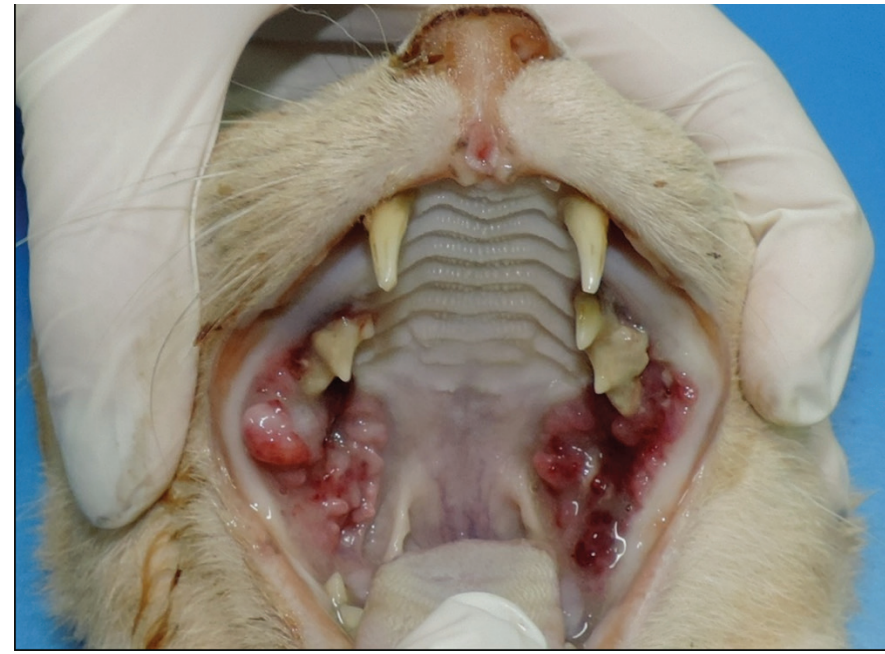

Fig.8. Marked nodular to vegetatively bilaterally symmetrical proliferation in the fauces of a cat with severe periodontal disease. 
mandible body, by dissociation of the body: mandibular branch thickness and by the absence of teeth. In these more severe cases, bone rarefaction, seen with multiple radiolucencies (Fig.10), demonstrated the extent of periodontal lesions. Individualized results are shown in Table 1.

\section{Cytopathological findings}

For better observation, cytopathological findings will be subdivided into those from the oral cavity, including gingival and fauces cytology, and those from the draining local lymph nodes.

Table 1. Results of physical examinations (intraoral examination - evaluation of teeth and of periodontal tissues) and radiographs of cats with periodontal disease

\begin{tabular}{|c|c|c|c|c|c|c|c|}
\hline & Calculus accumulation* & Gingivitis & $\begin{array}{c}\text { Gingival } \\
\text { retraction }\end{array}$ & Dental mobility* & $\begin{array}{c}\text { Furcation } \\
\text { exhibition* }\end{array}$ & $\begin{array}{c}\text { Alveolar bone } \\
\text { loss }\end{array}$ & Result \\
\hline Cat 1 & +++ & +++ & +++ & ++ & +++ & +++ & PDIII \\
\hline Cat 2 & +++ & +++ & +++ & ++ & +++ & +++ & PDIII \\
\hline Cat 3 & +++ & +++ & +++ & ++ & +++ & +++ & PDIII \\
\hline Cat 4 & + & + & - & - & - & - & PDI \\
\hline Cat 5 & ++ & ++ & ++ & + & - & + & PDII \\
\hline Cat 6 & +++ & +++ & +++ & +++ & +++ & +++ & PDIII \\
\hline Cat 7 & +++ & +++ & +++ & +++ & +++ & +++ & PDIII \\
\hline Cat 8 & +++ & +++ & +++ & +++ & +++ & +++ & PDIII \\
\hline Cat 9 & ++ & + & + & + & - & + & PDII \\
\hline
\end{tabular}

* The calculus accumulation, furcation exposure and dental mobility represented here in crosses (+ mild, ++ moderate, +++ severe), is equivalent to grades

I, II and III, previously described in the materials and methods; PD = periodontal disease (grades I, II and III).

Table 2. Other injuries found in the physical examination of cats with periodontal disease

\begin{tabular}{lccccc}
\hline & Toothlessness & Contact stomatitis & Chronic gingivostomatitis & Ulcerative faucitis & Persistent lymphadenopathy \\
\hline Cat 1 & Yes & Yes & No & No & No \\
Cat 2 & Yes & No & Yes & Yes & Yes \\
Cat 3 & Yes & No & No & No & No \\
Cat 4 & Yes & No & No & Yes & Yos \\
Cat 5 & Yes & No & No & No & No \\
Cat 6 & Yes & No & No & No & No \\
Cat 7 & Yes & Yes & No & No & No
\end{tabular}

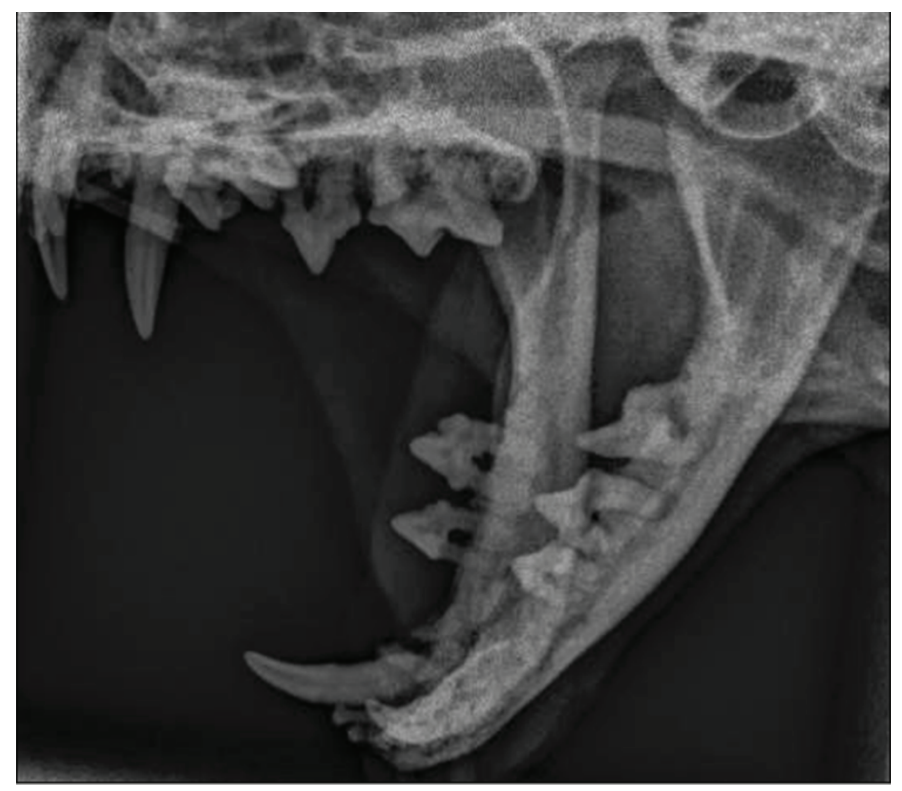

Fig.9. Radiographic image of the lower dental arch of a cat with severe periodontal disease. Note the loss of the jaw's horizontal bone line, which shows how much bone tissue has been remodeled.

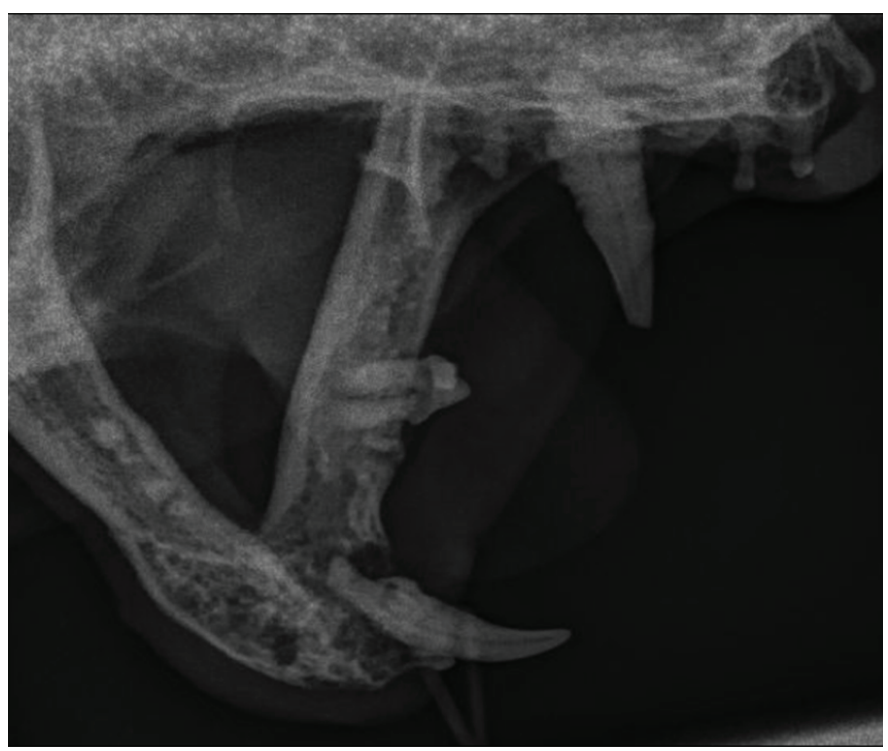

Fig.10. Radiographic image of the lower dental arch of a cat with severe periodontal disease. In addition to the absence of most teeth, we observe intense bone rarefaction, seen as a marked decrease in radiopacity. 
Cytopathological findings of the oral cavity. All cats with periodontal disease and the three control cats had their oral cavity evaluated cytopathologically. In the control cats' oral cavity, there was a large number of bacteria in the form of coccus and bacilli, a small number of epithelial cells, mainly intensely keratinized and anucleate cells, but also less keratinized and anucleate cells. Inflammatory cells, basically neutrophils, were scarce (Fig.11).

All cats with periodontal disease, but none of the control cats had intense cellularity and many bacteria. Neutrophils predominated, mostly with criteria that allowed them to be identified as necrotic ("degenerate neutrophils"). Many of the healthy neutrophils had cytoplasm full of bacteria, mainly coccus. Agglomerated neutrophils surrounding bacterial aggregates were frequent (Fig.11). Macrophages with cytoplasm

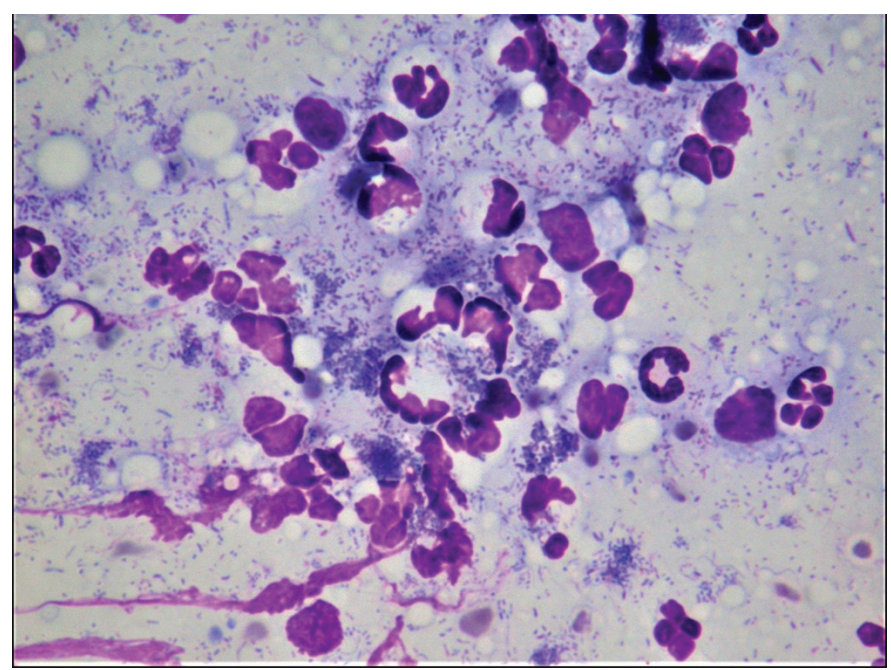

Fig.11. Gingival cytology of a cat with severe periodontal disease. Several neutrophils, mostly degenerated, amidst massive amounts of bacteria in the form of coccus. Panoptic stain, obj.40x.

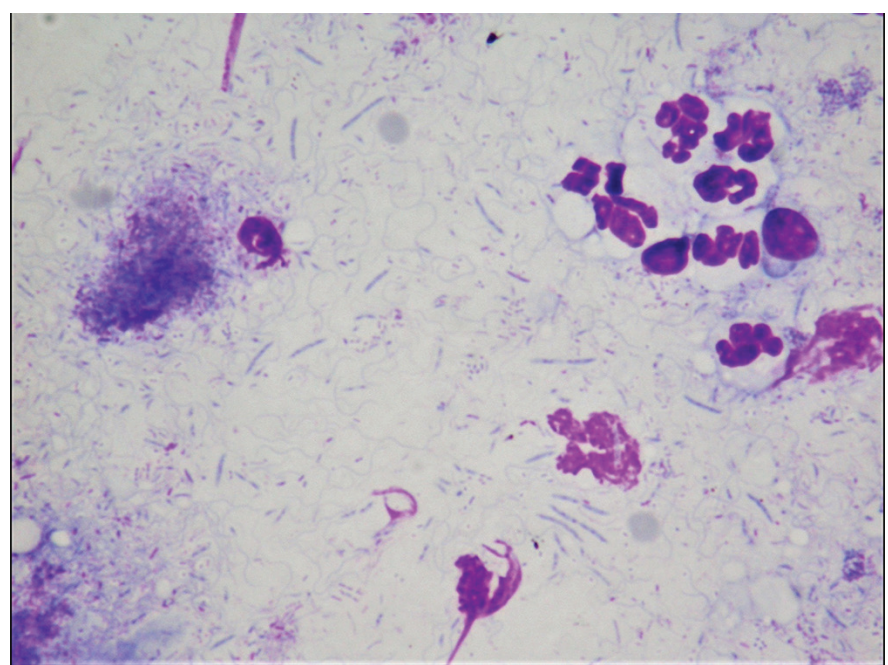

Fig.13. Gingival cytology of a cat with severe periodontal disease. Some neutrophils, mostly degenerate, and chromatin filaments (nuclear remnants) amidst massive amounts of bacteria in the form of single, curved, slightly longer bacilli than seen in Figure 12. Panoptic stain, obj.40x. full of cellular debris were sparse. Other inflammatory cells were less frequent and included eosinophils, lymphocytes, and plasma cells.

Bacteria distributed among the cells included aggregates of coccus, chain coccus (Fig.11), and diplococci accumulations. Bacilli of different thickness and length, straight (Fig.12) or curved (Fig.13), small or large (Fig.14), isolated or in chains, with or without aggregated intracellular acidophilic material could be seen in abundance. A large number of spirochetes were also present (Fig.15).

Of the cats with periodontal disease, two $(22.2 \%)$ and one (11.1\%) had ulcerative faucitis and chronic gingivostomatitis, respectively. In addition to the same oral cytopathological results previously described, these three cats presented a large amount of lymphocytes and plasma cells (Fig.16) in the

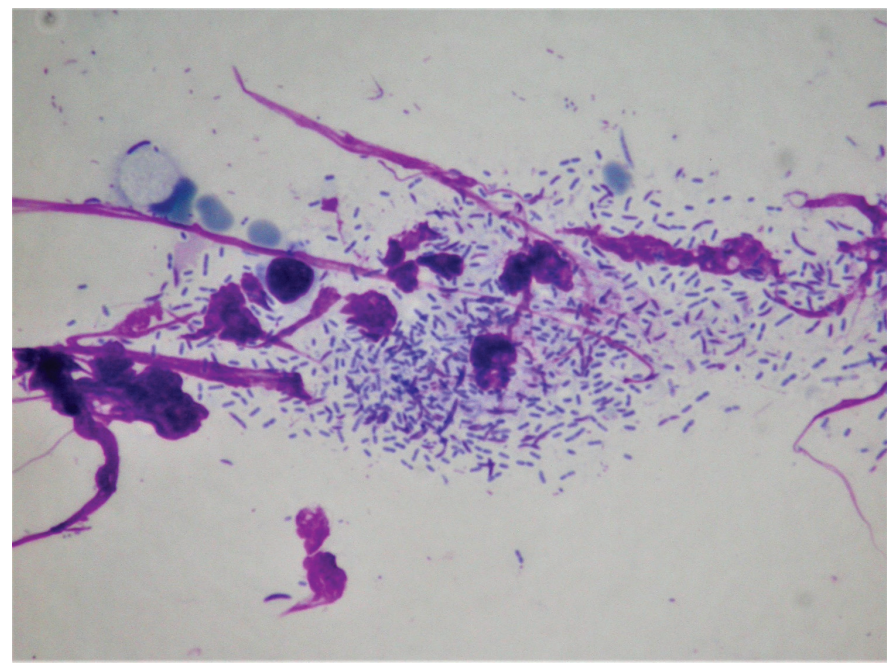

Fig.12. Gingival cytology of a cat with severe periodontal disease Some neutrophils and chromatin filaments (nuclear remnants) amidst massive amounts of bacteria in the form of small, short bacilli and often in pairs. Panoptic stain, obj.40x.

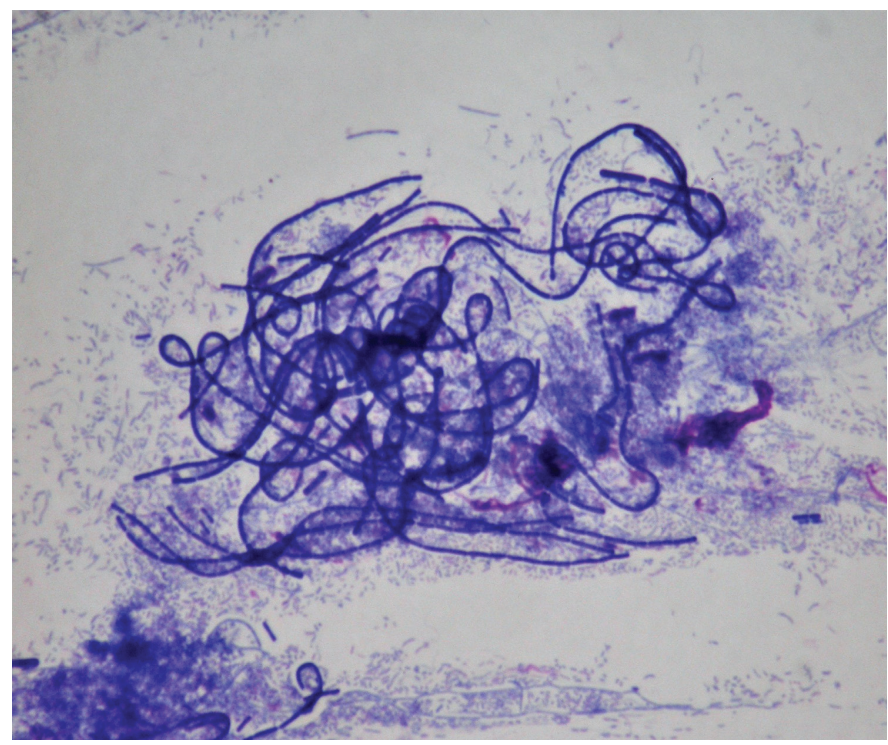

Fig.14. Gingival cytology of a cat with severe periodontal disease. Lots of bacteria in the form of large bacilli and forming chains of large extensions. Panoptic stain, obj.40x. 
cytology of the fauces and affected gums, including plasma cells loaded with cytoplasmic globules (Mott cells) and plasma cells with hyaline cytoplasm ("flame cells").

Nodal cytopathological findings. All cats with periodontal disease and the three control cats had their mandibular and retropharyngeal lymph nodes evaluated cytopathologically. In the control cats' lymph nodes, there was a predominant lymphoid population with morphological characteristics that allowed them to be included as mature (small mature lymphocytes not cleaved). A second lymphoid population, represented by a smaller proportion of cells, characterized by a larger size and less maturation, was also seen in all control cases (immature lymphocytes). Fewer plasma cells with typical cell morphology completed the nodal cell findings of these patients.

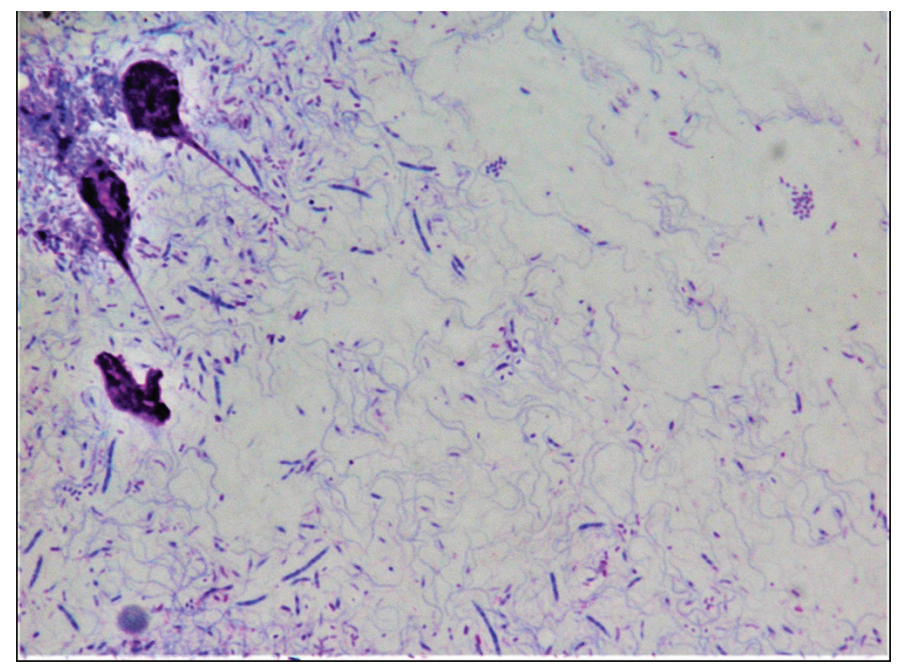

Fig.15. Gingival cytology of a cat with severe periodontal disease. Lots of bacteria in the form of spirochetes that intertwine at the bottom of the microscopic field. Bacteria similar to those seen in Figure 13 and chromatin filaments (nuclear remains) are present in lesser quantities. Panoptic stain, obj.40x.

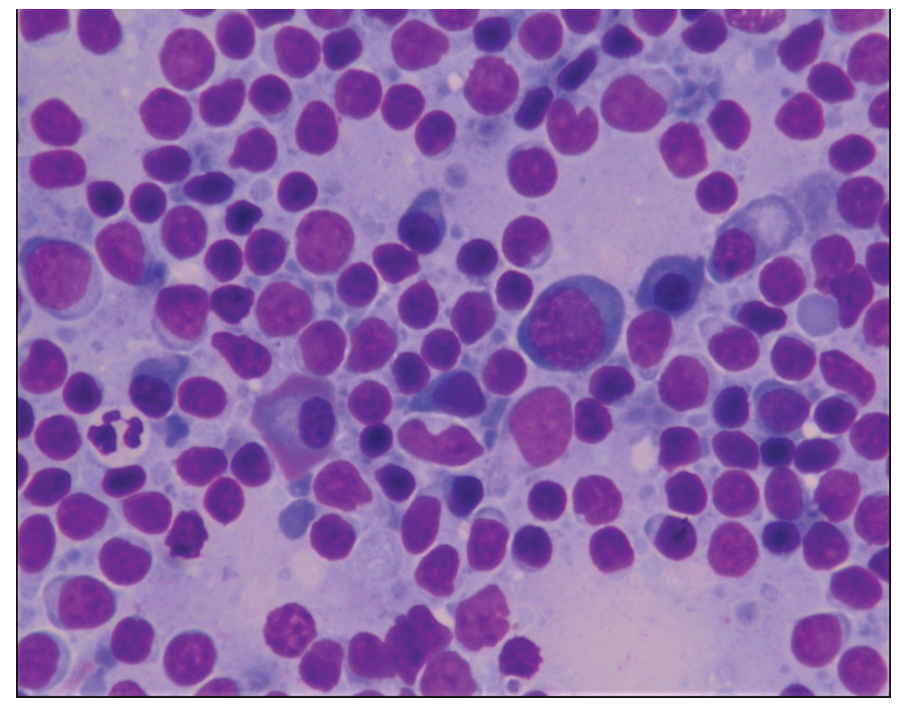

Fig.17. Nodal cytology of a cat with faucitis and severe periodontal disease. Intense lymphoid hyperplasia with plasmacytic differentiation. Panoptic stain, obj. 40x.
Of the nine cats with periodontal disease, six (66.7\%), one (11.1\%) of whom had lymphadenomegaly, had a similar cytopathological pattern but was richer in immature lymphoid cells and plasma cells. In these six cases, neutrophils were seen in moderate to severe amounts amid lymphocytes, characterizing a "nodal drainage reaction".

Of the nine cats with periodontal disease, three (33.3\%), who had lymphadenomegaly, had a different cytopathological pattern, not so much in cell types, but in their proportions. In these three cases, the number of immature plasma cells and lymphocytes was much greater than in other cats with periodontal disease and in control cats (Fig.17). Also, plasmacytic precursors (plasmablasts) (Fig.17), plasma cells loaded with cytoplasmic globules (Mott cells) (Fig.18), plasma cells with cytoplasmic crystals (Fig.19), and plasma

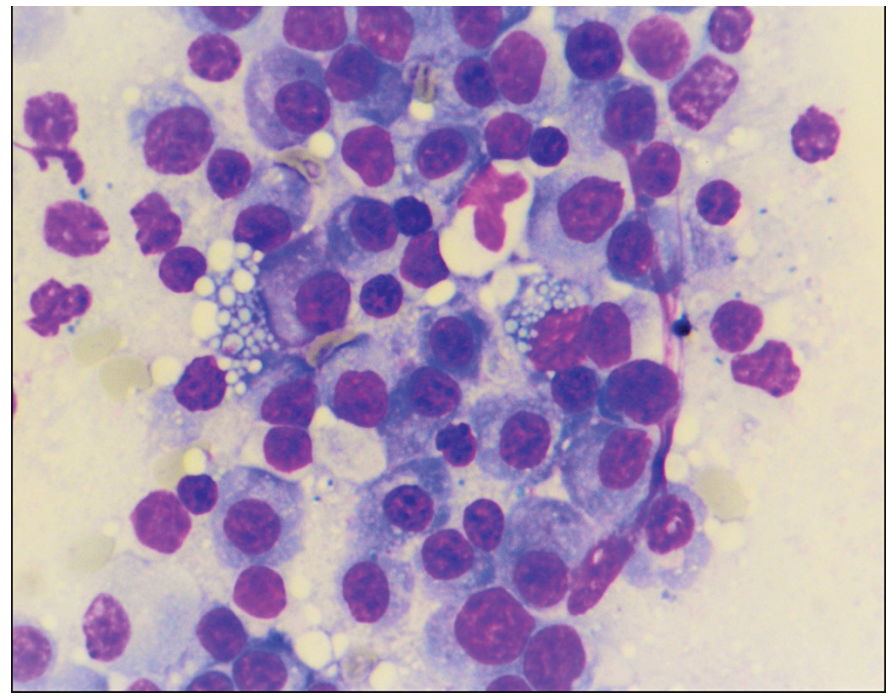

Fig.16. Cytology of the fauces of a cat with faucitis and severe periodontal disease. Observe the monomorphism of the inflammatory infiltrate, consisting almost exclusively of plasma cells, including two Mott cells. Panoptic stain, obj.40x.

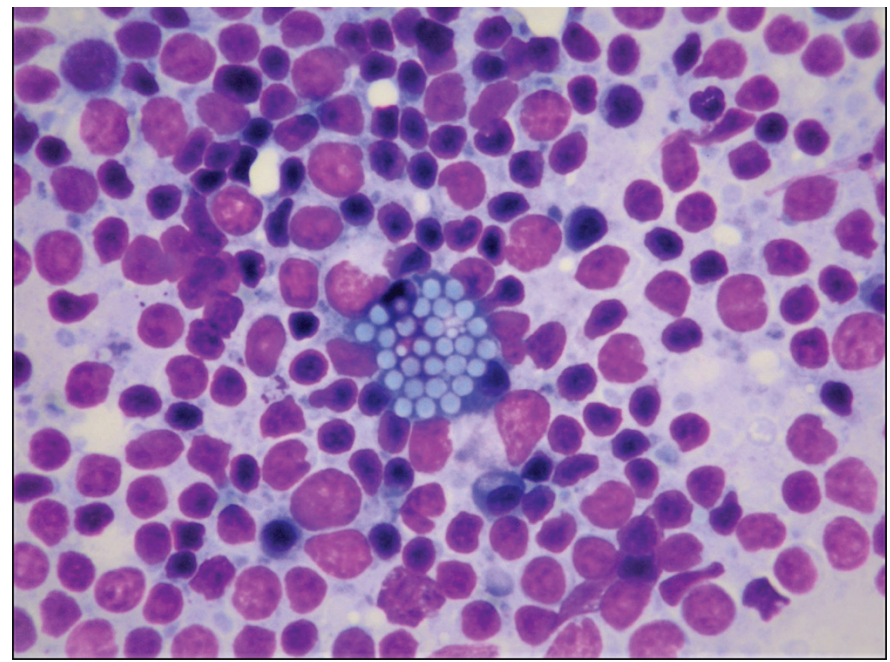

Fig.18. Nodal cytology of a cat with faucitis and severe periodontal disease. Observe the plasma cells with cytoplasm filled with large basophilic granules (Russel corpuscles) in the image (Mott cell). Panoptic stain, obj.40x. 
cells with hyaline cytoplasm ("flame cells") (Fig.20) were common (nodal plasmacytosis). The number of neutrophils was similar to that of other cats with periodontal disease. The nodal patterns of each patient can be found in Table 3.

\section{Virological findings}

All cats evaluated $(n=9,100 \%)$, including patients used as a control group ( $\mathrm{n}=3)$, tested negative for the presence of feline leukemia virus (FeLV) and antibodies against feline immunodeficiency virus (FIV) in the blood. Swabs from the oral cavity of four cats (three cats with periodontal disease $(3 / 9,33.3 \%)$ and a control cat $(1 / 3,33.3 \%)$ were positive in cell culture, as they exerted a cytopathic effect. After extracting the viral RNA and sequencing the base pairs, all were identified as feline calicivirus. Individualized results are shown in Table 4.

\section{DISCUSSION}

Behavioral changes observed in animals should not be neglected to prevent these suffering individuals from going

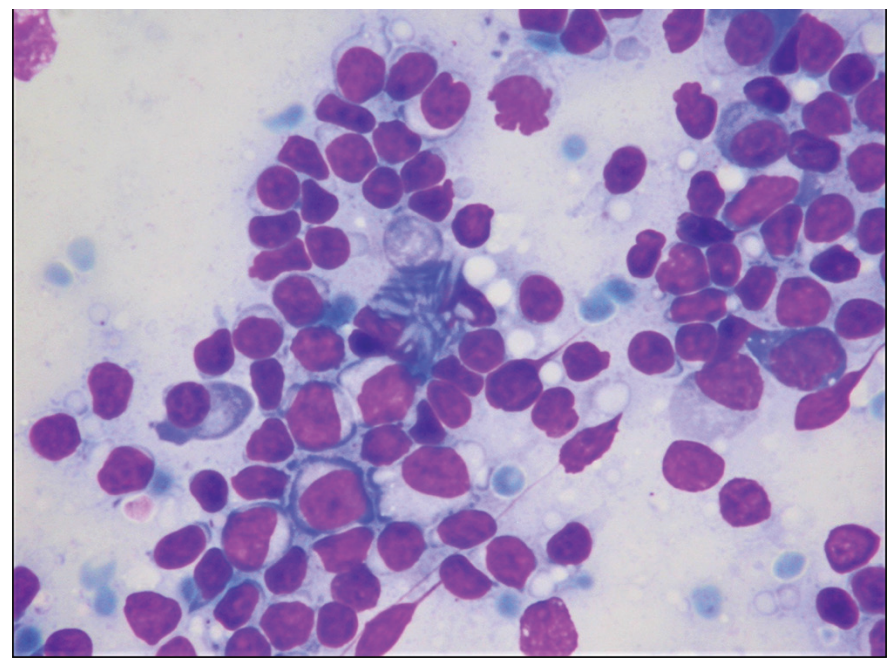

Fig.19. Nodal cytology of a cat with faucitis and severe periodontal disease. Observe the plasma cells with cytoplasm full of immunoglobulin crystals in the center of the image. Panoptic stain, obj.40x. unnoticed (Hellebrekers 2002). However, the classification of the intensity of the discomfort or pain experienced by the veterinary patient is difficult, even for species of intimate contact with humans, such as the cat (Posso \& Ashmawi 2012). The persistent exposure of the tongue, observed in cats with periodontal disease, can be considered a deviation from the patient's normal behavior and be related to discomfort or pain in the oral region (Landsberg et al. 2005).

Lymph nodes, interspersed in the lymph path, are structures made up of lymphoid tissue that act as genuine filters of everything that reaches them through the afferent lymphatic vessels (Dantas \& Siqueira 2000). The salivary glands, the intermandibular space, the tongue, and all other structures that comprise the "snout", are drained by the lymph nodes of the mandibular center (Dyce et al. 1997). Lymphadenomegaly means the increase in the lymph node's size, usually related to inflammatory processes or neoplasms (Fry \& McGavin 2009). The persistence of lymphadenomegaly in $44.4 \%$ of cats with periodontal disease indicates the course of a chronic inflammatory process. The inflammatory process is

Table 3. Relationship between periodontal disease, contact stomatitis, chronic gingivostomatitis, ulcerative faucitis, persistent lymphadenopathy and the nodal cytopathological pattern

\begin{tabular}{|c|c|c|c|c|c|c|}
\hline & $\begin{array}{c}\text { Periodontal } \\
\text { disease }\end{array}$ & $\begin{array}{c}\text { Contact } \\
\text { stomatitis }\end{array}$ & $\begin{array}{c}\text { Chronic } \\
\text { gingivostomatitis }\end{array}$ & $\begin{array}{l}\text { Ulcerative } \\
\text { faucitis }\end{array}$ & $\begin{array}{c}\text { Persistent } \\
\text { lymphadenopathy }\end{array}$ & $\begin{array}{c}\text { Nodal cytopathological } \\
\text { pattern }\end{array}$ \\
\hline Cat 1 & III & Yes & No & No & No & Drainage* \\
\hline Cat 2 & III & No & Yes & No & Yes & Plasmacytosis** \\
\hline Cat 3 & III & No & No & Yes & Yes & Plasmacytosis \\
\hline Cat 4 & I & No & No & No & No & Drainage \\
\hline Cat 5 & II & No & No & Yes & Yes & Plasmacytosis \\
\hline Cat 6 & III & No & No & No & No & Drainage \\
\hline Cat 7 & III & Yes & No & No & Yes & Drainage \\
\hline Cat 8 & III & No & No & No & No & Drainage \\
\hline Cat 9 & II & No & No & No & No & Drainage \\
\hline
\end{tabular}

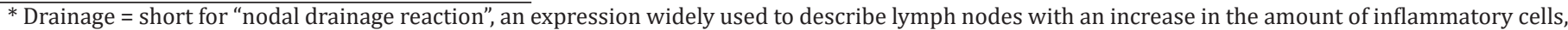

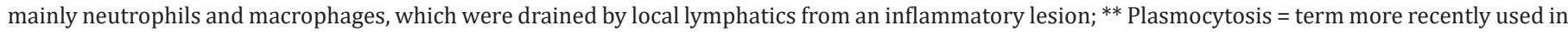

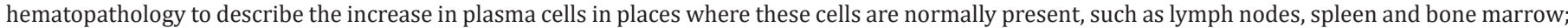
Previously plasmacytic hyperplasia or lymphoid hyperplasia with plasmacytic differentiation. 
Table 4. Relationship between periodontal disease, chronic gingivostomatitis, ulcerative faucitis, persistent lymphadenopathy and infection by feline leukemia virus, feline immunodeficiency, calicivirus and feline herpesvirus

\begin{tabular}{|c|c|c|c|c|c|c|c|c|}
\hline & Periodontal disease* & Chronic gingivostomatitis & Ulcerative faucitis & Persistent lymphadenopathy & FCV & FHV-1 & FeLV & FIV \\
\hline Cat 1 & III & No & No & No & No & No & No & No \\
\hline Cat 2 & III & Yes & No & Yes & No & No & No & No \\
\hline Cat 3 & III & No & Yes & Yes & No & No & No & No \\
\hline Cat 4 & I & No & No & No & No & No & No & No \\
\hline Cat 5 & II & No & Yes & Yes & No & No & No & No \\
\hline Cat 6 & III & No & No & No & Yes & No & No & No \\
\hline Cat 7 & III & No & No & Yes & No & No & No & No \\
\hline Cat 8 & III & No & No & No & Yes & No & No & No \\
\hline Cat 9 & II & No & No & No & Yes & No & No & No \\
\hline
\end{tabular}

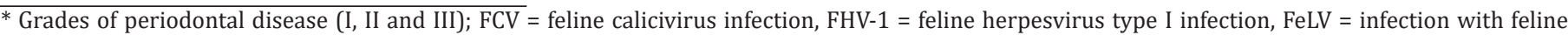
leukemia virus, FIV = infection by the feline immunodeficiency virus.

the organism's response to an injury, whether caused by the most varied etiological agents, microorganisms for example. The inflammation starts to be characterized as chronic when the stimulus that gave rise to the defense process extends for weeks or months (Kumar et al. 2005).

Periodontal disease is among the various diseases listed in the medical literature with a probable inflammatory course (Santos et al. 2012). With a prevalence close to $85 \%$ in adult dogs and cats, periodontal disease is a widespread disorder in the domestic cat (Reichart et al. 1984, Watson 1994). In addition to pain, caused by the variable degree of inflammation in the tissues that support the tooth, periodontal disease can lead to tooth loss and fractures in the jaw and mandible (Santos et al. 2012).

The feline oral cavity is short and wide, which facilitates physical examination, both of soft structures (vestibule lining tissues, hard and soft palates, palatoglossal and palatopharyngeal arches, palatine tonsils, frenulum, sublingual caruncle, and tongue) and hard (teeth) (Dyce et al. 1997). With 12 teeth less than the dog, felines have 30 teeth in permanent dentition, distributed between incisors, canines, premolars, and molars (West 1990). Between the third and sixth weeks of life, deciduous teeth eruption occurs when molars are not present. From the third month, permanent teeth appear, with the molars completing the feline dental arch at six months of age (Gioso 2003). Consisting of enamel (a white, calcified substance, very resistant and that covers the crown), dentin (which forms most of the tooth, presenting a central cavity, which houses the pulp) and cementum (a more flexible yellowish tissue), the teeth are inserted into the bone alveoli, both in the mandible and in the jaw (Santos 2012, Dyce et al. 1997). The set of tissues that partially cover, support, and protect teeth, we call periodontium: gingiva, alveolar bone, cementum, and periodontal ligament (Debowes 2004).

Among the various agents that can lead to PD, bacterial plaque is recognized as the primary etiologic agent (Domingues et al. 1999). Characterized as a cluster of established bacteria, both on the hard surface of the tooth and on soft tissue, plaque is also known as biofilm (Nascimento et al. 2006, Marinho \& Araújo 2007). Bacteria protect themselves in the extracellular matrix, consisting of polysaccharides, exopolysaccharides, and saliva. In biofilm, they are also grouped into microcolonies that communicate through chemical signals, establishing an efficient defense system (Overman 2000, Marinho \& Araújo 2007). The biofilm's oxygen concentration establishes the type of bacteria present: anaerobic in the deepest layers and aerobic in the most superficial of the bacterial plaque. The tooth's face turned to the tongue and tended to accumulate more biofilm, precisely because it exhibits lower oxygen (Marinho \& Araújo 2007).

The precipitation of minerals carried by saliva, such as calcium salts, mainly calcium carbonate and phosphate, on the biofilm (Corrêa \& Venturini 1996) results in dental calculus or tartar. By itself, dental calculus is inert, only causing periodontal disease associated with microorganisms in the biofilm (Gorrel et al. 2004). The accumulation of biofilm in the gingival margin and the dental groove facilitates the installation of more bacteria, which results in aggression to the gingiva and consequent inflammatory response characterizing gingivitis (Gioso 2003). As gingivitis progresses, the inflammatory process weakens the cementum's collagen fibers, leading to the detachment of the tooth's supporting ligament (Gorrel et al. 2004). Our study observed slight hyperemia in some cats' gingival margin, mainly in the premolar and canine teeth (mild periodontal disease), gum edema in premolars, molars, and possible canines (moderate periodontal disease). It was also verified that in cases where the periodontal disease was severe, the gingival retraction with exposure of the dental neck, leading to a reduction in the tooth (mobility). The formation justifies this finding and deepening of the periodontal pocket when the gingival sulcus reaches or exceeds $5 \mathrm{~mm}$, and the alveolar resorption responds to inflammation (Ferro et al. 2008).

The inflammation initially promoted by gingivitis and maintained by PD can extend to the oral cavity's mucous membranes, manifesting as chronic ulcerative paradental stomatitis (Gelbert 2009). These lesions occur on surfaces opposite the biofilm, causing pain and salivation, as seen in two of the cats described here. In addition to the mucous membranes, the region of fauces (the mucous structure that covers glossopalatine arches) can also be reached by inflammation, making it difficult to eat food (Niza et al. 2004). It explains persistent salivation, halitosis, and abnormal positioning of the tongue, observed in two patients. However, the animal's reasonable body condition suggests that discomfort did not prevent food intake.

In a physiological condition, the bone mass present in the body results from the balance between matrix deposition and bone resorption; this phenomenon is called bone remodeling. This process is beneficial for the organism, as it maintains the homeostasis of the serum level of calcium and phosphorus 
(Cho et al. 1991). The remodeling results from a complex interaction of macrophages, osteoclasts, osteocytes, and osteoblasts, leading to the skeleton's renewal from time to time (Manolagas 2000). However, alveolar bone structures are not affected by bone remodeling, probably due to the absence of receptors sensitive to bone remodeling mediator's chemical stimuli, in the cells that colonize the root of the teeth cementoblasts (Lindskog et al. 1987, Cho et al. 1991). An erosive process is observed in the tooth structure (Girard et al. 2010). Formerly referred to as "feline caries", the tooth resorption lesion (LRD), is characterized by erosion in the hard tissues of the tooth and probably reaching the pulp region (Niemiec 2014). In our study, we observed in the PD group, a variable degree of bone loss in the alveoli, in the mildest cases, related to periapical lesions, resulting from the chronic inflammatory process (Bellows 2010), and even bone reduction in the mandible, which could lead to the occurrence of fractures.

The oral injury was already associated with the presence of FHV when Hargis and Ginn, in the late 1990s, sought to establish a possible relationship between FHV and chronic gingivostomatitis (FCGS) that affects this species (Hargis et al. 1999). Later, in the early 2000s, Lommer and Verstraete were able to isolate FHV and FCV in the saliva of $88 \%$ of cats with FCGS (Lommer \& Verstraete 2003). FIV has also been found in about $50 \%$ of cats with FCGS (Cognet et al. 2001). However, the association between FeLV and FCGS has also been investigated without conclusive results (Harley 2003). In our study, the only virus found, both in cats with periodontal disease and in control cats (33.3\%), was FVC.

In addition to viruses, bacteria established in the oral cavity, especially anaerobic ones, have been listed as possible causative / inciting agents for FCGS (Love et al. 1990). All cats, both those with periodontal disease and those with a healthy oral cavity (control cats), presented a significant number of bacteria, in the form of coccus and bacilli, in addition to epithelial cells. If the number of inflammatory cells was low in the control cats, the opposite was found in cats with periodontal disease, mainly neutrophils, and macrophages, all in full phagocytosis activity of the local bacteria. The degeneration observed in neutrophils is related to the synthesis and release of endotoxins by the site's bacteria. When the neutrophil becomes degenerate, its ability to control fluid hemostasis ceases, leading to cytoplasmic edema or degeneration (Meinkoth et al. 2009). Cells such as eosinophils, lymphocytes, and plasma cells were also detected, but without numerical expression. These findings are consistent with the inflammatory process present in periodontal disease.

Ulcerative faucitis and FCGS have also been observed in some cats with periodontal disease. The cytological evaluation revealed, in addition to the inflammatory cells (neutrophils and macrophages), the presence of lymphocytes and plasma cells, some of which are characterized as Mott cells and "flame cells", due to the peculiarities presented in the cytoplasm. When stimulated to produce antibodies, B lymphocytes differentiate into plasma cells, cells with an eccentric and round nucleus. When the plasma cells exhibits a cytoplasm with large vacuoles and full of immunoglobulins (Russell's corpuscles), it is called a Mott cell, reinforcing the confirmation of a scenario in which inflammation predominates (Meinkoth et al. 2009).

\section{CONCLUSION}

The presence of inflammatory cells (neutrophils, macrophages, lymphocytes, and plasma cells), collected from lesions of oral structures (mucous membranes and fauces), revealed an important inflammatory scenario. Different types of bacterial communities live in perfect harmony with each other and, protected in structures called biofilms, which mineralized (dental calculations), promote a mild inflammatory response that initially does not compromise the periodontal structure that supports the tooth in the bone alveolus. When persistent, this scenario progresses to periodontal disease, closely associated with chronic inflammation and its consequent destruction of the periodontium, tooth loss, and, ultimately, intense bone matrix loss.

Acknowledgments.- Douglas M. Lorenzetti has scholarship from "Programa Institucional de Bolsas de Iniciação Científica” (PIBIC), “Conselho Nacional de Desenvolvimento Científico e Tecnológico" (CNPq), "Universidade Federal de Santa Maria” (UFSM), Brazil, and Alana Herbichi from "Programa Institucional de Bolsas de Iniciação Científica” (PROBIC), "Fundação de Amparo à Pesquisa do Estado do Rio Grande do Sul” (FAPERGS), UFSM, Brazil.

Conflict of interest statement.- The authors have no competing interests.

\section{REFERENCES}

Argenta F.F., Ramos B.C., Fredo G., Laisse C.J.M., Rolim V.M., Cargnelutti J.F., Flores E.F., Pavarini S.P., Costa F.V.A. \& Driemeier D. 2017. Ulcerative dermatitis caused by feline herpesvírus type 1 in a domestic cat. Semina, Ciênc. Agrárias 38(n4supl.1):2857-2862.<https://dx.doi.org/10.5433/16790359.2017v38n4Supl1p2857>

Bellows J. 2010. Radiology Feline Dentistry: oral assessment, treatment and preventative care. Willey-Blackwell: USA, p. 39-83.

Chaudieu G. \& Blaizoit A. 1999. Gingivites et stomatitis felines. Pratique Médicale et Chirurgicale de l'Animal de Compagnie 34:135-144.

Cho M.I., Lin W.L. \& Garant P.R. 1991. Occcurrence of epidermal growth-binding sites during differentiation of cementoblasts and periodontal ligament fibroblasts of youngrat: a light and electron microscopic radioautographic study. Anat. Rec. 231(1):14-24. <https://dx.doi.org/10.1002/ar.1092310104> $<$ PMid:1750709>

Cognet R., Mesnard E., Stambouli F. \& Gauthier 0. 2001. Chronic Gingivostomatitis and Viral Infections in a Population of 54 Cats. Livro de Resumos. 10th ed. EVD Congress, Berlin.

Corrêa H.L. \& Venturini M.A.F.A. 1996. Cálculo dentário subgengival. Clín Vet. 1(5):6-7.

Dantas C.J.S., Siqueira J.F. 2000. Mecanismos Celulares e Moleculares da Inflamação. MEDsi, Rio de Janeiro, p.45-50.

Debowes L.J. 2004. Odontologia: aspectos periodontais, p.1189-1205. In: Ettinger S.J. \& Feldman E.C. (Eds), Tratado de Medicina Interna Veterinária: doenças do cão e do gato. 5ª ed. Guanabara Koogan, Rio de Janeiro.

Domingues L.M., Alessi A.C., Schoken-Iturrino R.P. \& Dutra L.S. 1999. Microbiota saprófita associada à doença periodontal em cães. Arq. Bras. Med. Vet. Zootec. 51(4):329-332. <https://dx.doi.org/10.1590/S010209351999000400007>

Dyce K.M., Sack W.O. \& Wensing C.J.G. 1997. Tratado de Anatomia Veterinária, p.198-200. 2ª ed. Guanabara Koogan, Rio de Janeiro.

Ferro D.G., Correa H.L. \& Venturini M.A.F.A. 2008. Periodontia Veterinária (I): o periodonto e a moléstia periodontal. Nosso Clínico 68:6-10.

Fry M.M. \& McGavin M.D. 2009. Medula óssea, células sanguíneas e sistema linfático, p.778-780. In: McGavin M.D. \& Zachary J.F. (Eds), Bases da Patologia em Veterinária. 4aㅡ ed. Mosby, Rio de Janeiro. 
Gawor J.P., Reiter A.M., Jodkowska K., Kurski G., Wojtacki M.P. \& Kurek A. 2006. Influence of diet oral health in cats and dogs. J. Nutrit. 136(Supl.7):2021S2023S. <https://dx.doi.org/10.1093/jn/136.7.2021S><PMid:16772485>

Gelbert H.B. 2009. Sistema digestório, p.305-308. In: McGavin M.D. \& Zachary J.F. (Eds), Bases da Patologia em Veterinária. 4⿳a ed. Mosby, Rio de Janeiro.

Gioso M.A. 2003. Odontologia para Clínicos de Pequenos Animais. 3ạ ed. FMVZ-USP, São Paulo.

Girard N., Servet E., Hernnet P., Biourge V. 2010. Tooth resorption and vitamin D3 status in cats fed premium dry diets. J. Vet. Dent. 27(3):142-147. <https://dx.doi.org/10.1177/089875641002700301><PMid:21038831>

Gorrel C., Gracis M., Hennet P. \& Verhaert L. 2004. Focus: doença periodontal no cão. Ed. Especial, Aniwa Publishing, Paris.

Hargis A.M., Ginn P.E., Mansell J.E.K.L. \& Garber R.L. 1999. Ulcerative facial and nasal dermatitis and stomatitis in cat associated with feline herpesvirus 1. Vet. Dermat. 10(4):267-274. <https://dx.doi. org/10.1046/j.1365-3164.1999.00145.x>

Harley R. 2003. Feline gingivostomatitis. Livro de Resumos Hill's European Symposium on Oral Care. p. 34-41. Amsterdan.

Hellebrekers L.J. 2002. Dor em Animais, p.11-13. Manole, São Paulo.

Henzel A., Brum M.C.S., Lautert C., Martins M., Lovato L.T. \& Weiblen R. 2012. Isolation and identification of feline calicivirus and feline herpesvírus in Southern Brazil. Braz. J. Microbiol. 43(2):560-568. https://dx.doi. org/10.1590/S1517-83822012000200017>

Holmstrom S.E. 1992. Feline endodontics. Vet. Clin. N. Am., Small Anim. Pract. 22(6):1433-1451. <https://dx.doi.org/10.1016/S0195-5616(92)50136-X>

Holmstrom S.E. 2012. Veterinary dentistry in senior canines and felines. Vet. Clin. N. Am., Small Anim. Pract. 42(4):793-808. <https://dx.doi. org/10.1016/j.cvsm.2012.04.001> <PMid:22720814>

Ingham K.E., Gorrel C. \& Bierer T.L. 2002. Effect of a dental chew on dental substrates and gengivitis in cats. J. Vet. Dent. 19(4):201-204. <https:// dx.doi.org/10.1177/089875640201900403><PMid:12593097>

Kumar V., Abbas A.K. \& Fausto N. 2005. Bases Patológicas das Doenças: Robbins and Cotran patologia. 4⿳亠丷a ed. Elsevier, Rio de Janeiro, p.50-83.

Landsberg G., Huthausen W. \& Ackerman L. 2005. Problemas Comportamentais do Cão e do Gato. 2ª ed. Roca, São Paulo, p.165-167.

Lindskog S., Blomlöf L. \& Hammrström L. 1987. Comparative effects of parathyroid hormone on osteoblasts and cementoblasts. J. Clin. Periodontal. 14(7):386-389. <https://dx.doi.org/10.1111/j.1600-051x.1987.tb01541.x> <PMid:3476515>

Lommer M.J. \& Verstraete F.J. 2003. Current oral shedding of feline calicivirus and feline herpesvirus I in cats with chronic gingivostomatitis. Oral Microbiol. Immunol. 18(2):131-134.<https://dx.doi.org/10.1034/j.1399302x.2003.00033.x> <PMid:12654105>
Love D.M., Vekselstein R. \& Colling S. 1990. The obligate and facultatively anaerobic bacterial flora of the normal feline gingival margin. Vet. Microbiol. 22(2/3):267-275. <https://dx.doi.org/10.1016/0378-1135(90)90114-b> $<$ PMid:2353448>

Manolagas S.C. 2000. Birth and death of bones cells: basic regulatory mechanisms and implications for the pathogenesis and treatment of osteosporosis. Endocr. Rev. 21(2):115-137. <https://dx.doi.org/10.1210/ edrv.21.2.0395> <PMid:10782361>

Marinho B.V.S. \& Araújo A.C.S. 2007. 0 uso de enxaguatórios bucais sobre a gengivite e o biofilme dental. Inter. J. Dent. 6(4):124-131.

Meinkoth J.H., Cowell R.L. \& Tyler R.D. 2009. Tipos celulares e critérios de malignidade. In: Cowell R.L., Tyler R.D., Meinkoth J.H. \& DeNicola D.B. Diagnóstico Citológico e Hematologia de Cães e Gatos. 3a ed. MedVet, São Paulo, p.20-25.

Nascimento D.F.F., Silva A.M. \& Marchini L. 2006. O papel das bactérias orais em doenças sistêmicas. Revta ABO Nacional 14(2):117-122.

Niemiec B.A. 2014. Feline dental radiography and radiology: a primer. J. Fel. Med. Surg. 16(11):887-899. <https://dx.doi.org/10.1177/1098612X14552366> <PMid:25344459>

Niza M.M.R.E., Mestrinho L.A. \& Vilela C.L. 2004. Gengivo-estomatite crónica felina: um desafio clínico. RPCV 99(551):127-135.

Overman P.R. 2000. Biofilm: a new view of plaque. J. Cont. Dent. Pract. 1(3):18-29. <PMid:12167880>

Posso I.P. \& Ashmawi H.A. 2012. Princípios gerais do tratamento da dor, p.29-31. In: Fantoni D. (Ed.), Tratamento da Dor na Clínica de Pequenos Animais. Elsevier, Rio de Janeiro.

Reichart P.A., Durr U.M., Triadan H. \& Vickendey G. 1984. Periodontal disease in the domestic cat. A histopathologic study. J. Periodont. 19(1):67-75. <https://dx.doi.org/10.1111/j.1600-0765.1984.tb01197.x ><PMid:6232370>

Santos N.S., Carlos R.S.A. \& Albuquerque G.R. 2012. Doença periodontal em cães e gatos: revisão de literatura. Medvep 10(32):1-67.

Silva A.P., Flores M., Mazaro R., Luz F., Silva M. \& Fighera R.A. 2019. Oral lesions and retroviruses in shelter cats. Pesq. Vet. Bras. 39(7):516-522. <https://dx.doi.org/10.1590/1678-5150-pvb-5892>

Watson A.D.J. 1994. Diet and periodontal disease in dogs and cats. Austr. Vet. J. 71(10):313-318. <https://dx.doi.org/10.1111/j.1751-0813.1994. tb00905.x> <PMid:7848177>

West L. 1990. Anatomy: the enigma of feline dentistry. J. Vet. Dent. 7(3):16-17.

Whyte A., Bonastre C., Monteagudo L.V., Les F. \& Obon J. 2014. Canine stage 1 periodontal disease: a latent pathology. Vet. J. 201(1):118-120. <https:// dx.doi.org/10.1016/j.tvjl.2014.05.005> <PMid:24878263> 